\title{
CORYNOSOMA ACANTHOCEPHALANS IN THEIR PARATENIC FISH HOSTS IN THE NORTHERn BaLtic Sea
}

\author{
SINISALO T.* \& VALTONEN E.T.*
}

\section{Summary:}

Cystacanth stages of three Corynosoma (Acanthocephala) species, C. strumosum and C. semerme, and a new species in the Bothnian Bay, C. magdaleni, were studied in the fourhorn sculpin (Myoxocephalus quadricornis) in 1996-1997. The length of the trunk and proboscis differentiated the three species in the fish. The stability of the Corynosoma infection was studied by comparing the present results with those collected from the same areas (central and coastal) in 1977-1982 (Valtonen, 1983a). As C. magdaleni and C. strumosum were not separated at that time, the joint infections of these two species (called "C. strumosum") were compared. The stability of infection with $C$. semerme in the central Bothnian Bay was noticeable (prevalences were 82.9 in earlier period and $81.9 \%$ in later period), while the prevalences of "C. strumosum" in the same areas had decreased $(2)$ and $13.5 \%$, respectively). This is suggested to be due to the disappearance of the marine bull-rout, Myoxocephalus scorpius from the Bothnian Bay during the 1990s due to an overall decline in salinity throughout the Baltic Sea. In the coastal area Corynosoma infection was clearly lower than in central area in both periods.

KEY WORDS : paratenic hosts, seals, Corynosoma, stability, Myoxocephalus quandricornis, Baltic Sea.
Résumé : LES ACANTHOCÉPHALES DU GENRE CORYNOSOMA CHEZ LEUR hÔte PaRaténique du NORD DE la MER BaltiQue

En 1996-1997, nous avons étudié les stages cystacanthes de trois espèces de Corynosoma (Acanthocephala), C. strumosum et C. semerme, ainsi qu'une nouvelle espèce C. magdaleni parasite du chabot à quatre cornes (Myoxocephalus quadricornis) dans le golfe de Bothnie. Les longueurs du tronc et du proboscis permettent de différencier les trois espèces de parasites. La stabilité temporelle de l'infection par Corynosoma est étudiée en comparant nos résultats à ceux obtenus dans la même zone géographique (centrale et côtière) en 1977-1982 Naltonen, 1983a). Comme C. magdaleni et C. strumosum n'étaient pas différenciées à cette époque, elles ont été groupées sous l'appellation "C. strumosum" pour les comparaisons. La stabilité de l'infestation par C. semerme dans la partie centrale du golfe de Bothnie est remarquable lles prévalences étaient de $82,9 \%$ lors de la première étude et $81,9 \%$ pour notre étude), alors que les prévalences de "C. strumosum" dans la même zone géographique ont diminué de $21 \%$ à 13,5\%. Il est suggéré que cela puisse être lié à la disparition du chabot à épines courtes,

Myoxocephalus scorpius, du golfe de Bothnie durant les années 1990 à la suite d'une baisse générale de la salinité dans la Mer Baltique. Dans la zone côtière, et pour les deux périodes d'étude, l'infestation par Corynosoma était nettement inférieure à celle trouvée dans la zone centrale.

MOTS CLÉS : hôte paraténique, phoque, Corynosoma, stabilité, Myoxocephalus quandricornis, Mer Baltique.

Corynosoma strumosum (Rudolphi, 1802) Lühe, 1904 and C. semerme (Forsell, 1904) Lühe, 1905 are the most widely distributed acanthocephalan species among oceanic seal populations (Dailey, 1975; Popov et al., 1980; Shults, 1982; Strauss et al., 1991; Measures \& Gosselin, 1994). However, C. magdaleni (Montreuil, 1958) has rarely been reported. It was described from a few grey seals captured in the Gulf of St. Lawrence in Canada (Montreuil, 1958) and from three ringed seals from the Gulf of Finland (Delyamure et al., 1980). Later C. magdaleni was found in grey seals of the southwestern archipelago of Finland around the Aland Islands (Nickol et al., 2002). The cystacanth stage of C. magdaleni has so far been reported only from the anadromous brook charr (Salvelinus fontinalis) in eastern Canada (Frimeth, 1987 a, 1987b).

Only C. strumosum and C. semerme were recorded in earlier studies of fish and seals from the Bothnian Bay (Helle \& Valtonen, 1980, 1981; Valtonen 1983a, 1983b).

\footnotetext{
* Department of Biological and Environmental Science, University of Jyväskylä, P.O. Box 35 (YAC341), 40351 Jyväskylä, Finland. Correspondence: Tuula Sinisalo.

Tel.: +358-40-755 2055 - Fax: +358-14-2602321

E-mail: tsinisal@bytl.jyu.fi
} 
However Nickol et al. (2002) recently redescribed the adult stages of C. magdaleni and C. strumosum. We suggest that the previously unclear description of C. strumosum in relation to C. magdaleni caused confusion and that $C$. magdaleni was consequently not detected.

The occurrence and abundance of definitive, paratenic and intermediate hosts of Corynosoma in the Baltic Sea have all varied during recent decades. Ringed seal numbers collapsed to about 2,500 individuals in the 1980s (Helle, 1986; Härkönen \& Lunneryd, 1992). Both the ringed and the grey seals suffered from hunting and reproduction abnormalities caused by pollution, which has led to a lowered reproductive capacity (Helle, 1980, 1986; Harding \& Härkönen, 1999). After hunting was prohibited in 1988 the stocks of both seal species recovered. In 1996, the population sizes of both seal species were about 5,500 individuals each, and increasing grey seal colonies in particular have been recorded in central and northern parts of the Baltic Sea (Harding \& Härkönen, 1999). Ringed seal is a resident species in the Bothnian Bay (Helle \& Valtonen, 1981) but grey seals only visit the area in the spring (Helle, pers. comm.).

The intermediate host of Corynosoma, Monoporeia affinis, is the most common benthic crustacean among the macrozoobenthos of the Bothnian Bay and its abundance has been reported to vary in the coastal area of the Bothnian Bay but to be more stable in the deeper central areas of the sea (Andersin et al., 1978; Valtonen, 1983a; Lindström, 1991; Wikner, 1996).

In the study area of the Bothnian Bay the brackish water has a salinity of $3 \%$ (Haapala \& Alenius, 1994). The fish fauna includes about 30 reproducing species, most of which are of freshwater origin, but several marine fish species also reproduce in the area (Andreasson \& Petersson, 1982). Among the changes in fish fauna in the area from 1980s to present is the disappearance of the bull-rout from the Bothnian Bay (Timola, pers. comm., Bothnian Bay Research Station, University of Oulu). In the earlier study of Valtonen (1983a) on the paratenic hosts of Corynosoma species in the Bothnian Bay, the bull-rout was the most intensively parasitized fish.

The aim of this study is three fold:

- To examine population differences between C. magdaleni and C. strumosum at their cystacanth stages. - To study the stability of Corynosoma infections in the Bothnian Bay by comparing the results of the present findings with those collected in 1977-1982 from the same area and using the same sampling procedure and methods as in the study of Valtonen (1983a).

- To study the local distibution of Corynosoma species in fish in the Bothnian Bay by comparing central and coastal areas.

\section{MATERIALS AND METHODS}

$\mathrm{F}$ ish samples were collected between August 1996 and June 1997. A total of 340 fourhorn sculpins (Myoxocephalus quadricomis) were caught by gill nets from the coastal area A (see Fig. 1) (the mean depth approx. $11 \mathrm{~m}$ ) and central area B (see Fig. 1) (the mean depth approx. $40-45 \mathrm{~m}$ ) of the Bothnian Bay in the northern part of the Gulf of Bothnia. Two samples were collected from the coastal area in June $(\mathrm{n}=29)$ and October $(\mathrm{n}=52) 1997$, and three samples from the deeper central area in August $1996(n=107)$ and June $(\mathrm{n}=38)$ and October $(\mathrm{n}=114)$ 1997. Sampling methods and areas were the same as in the studies of Valtonen (1983a). In addition, we examined 42 bull-rout (Myoxocephalus scorpius) between March and April 1999 from the southern part of the Gulf of Bothnia, area C (see Fig. 1), where the salinity is double that in the Bothnian Bay $(7 \% 0)$. Internal organs and the mesenteries of the sculpins were examined for parasites. After relaxation in water for at least two hours, the parasites were conserved in $70 \%$ ethanol, stained with Mayer's carmalum, dehydrated in ethanol, cleared in xylene, and mounted in Canada balsam. Corynosoma specimens (60 specimens of C. semerme, 33 specimens of C. magdaleni and seven specimens of C. strumosum) were identified by measuring the length of their trunk and proboscis and recording the extent of the trunk spines (Nickol et al., 2002). Canonical discriminant functions were used to differentiate the species at the cystacanth stage.

Mean abundance, mean intensity and prevalence were calculated according to Bush et al. (1997). The occurrence of Corynosoma assemblages in the coastal and in the central areas was compared by Pearson $\chi^{2}$-test. The relationship between the habitats (coastal vs central) and the time periods (1977-1982 vs. 1996-1997) for the Corynosoma infections was examined using logistic regression analysis. The automated forward stepwise variable selection procedure was applied to select the model that best fitted the data (Forward LR). Variable selection was repeated using the automated backward stepwise elimination procedure (Backward LR). By comparing hierarchical sets of regression models, the significance of each interaction and main effect was calculated using likelihood ratio statistics if forward and backward methods did not result in the same model. All statistical analyses were performed using SPSS Professional Statistics 10.0 (Norusis/SPSS Inc. 1997).

In this study, we use the term "C. strumosum" to refer to both C. magdaleni and C. strumosum when comparing the two study periods and when studying the stability of the infection. 
Fig. 1. - Map of the Bothnian Bay and its location within the Baltic Sea. Research areas: A, $\mathrm{B}$ and $\mathrm{C}$ are given as also 20 and 40 metre isobaths.

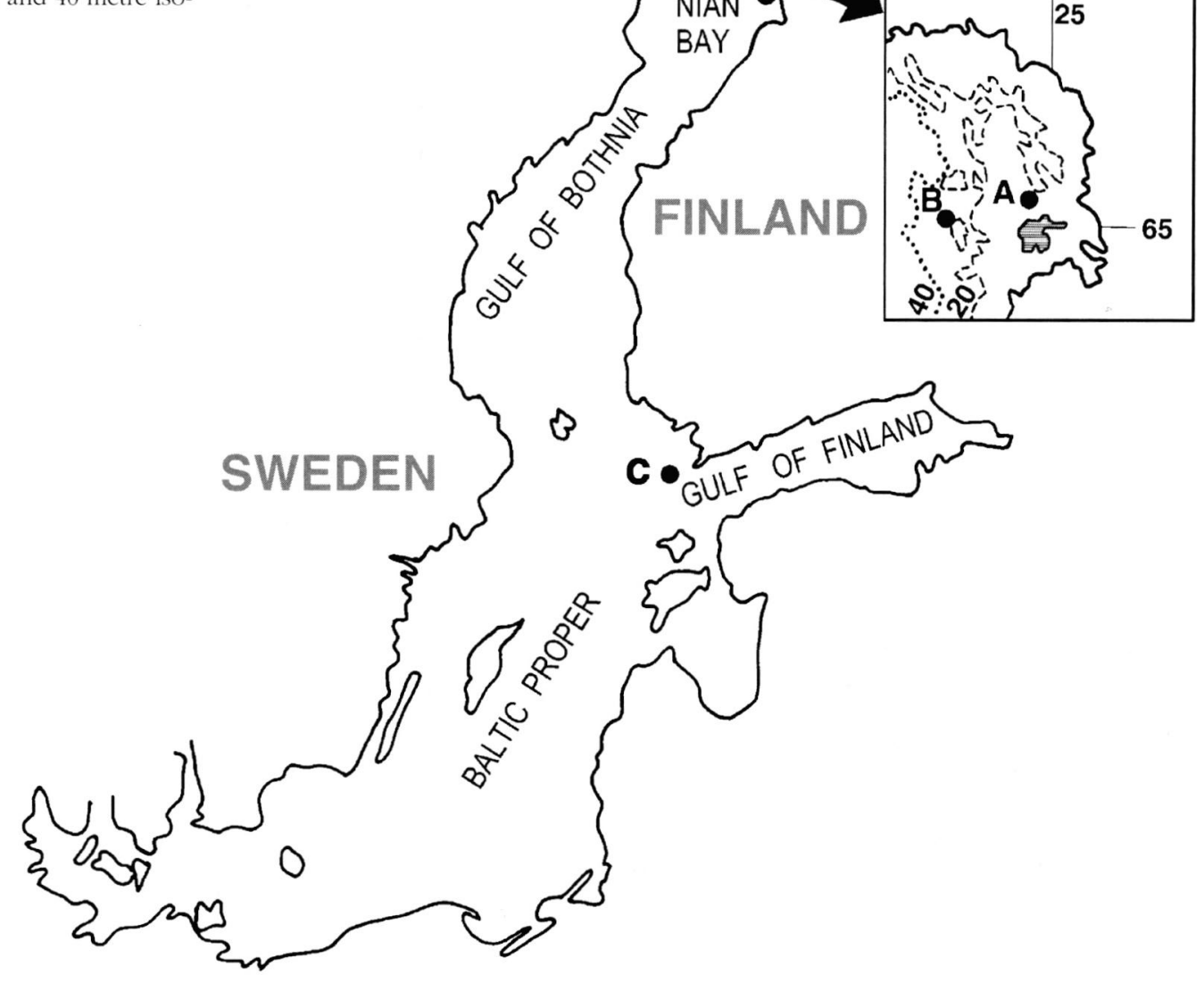

RESULTS

T The mean trunk and proboscis length of C. semerme, C. strumosum and C. magdaleni cystacanths diverged in the paratenic hosts (Table I). C. strumosum has, on average, the longest trunk, whereas C. semerme is clearly the shortest, differentiating C. semerme from C. strumosum. The range of the trunk length of C. strumosum partly overlaps that of C. magdaleni. The mean length of the proboscis was shortest in C. magdaleni $(420 \mu \mathrm{m})$ and longest in C. strumosum $(590 \mu \mathrm{m})$. The three Corynosoma species were differentiated by the length of the trunk and proboscis (Fisher's linear discriminant analysis, Wilk's Lambda $=0.241, \chi^{2}=279.451, p<0.001$, function 1 ; eigenvalue $=2.245$, function 2 ; eigenvalue $=0.278$ ) The percentages of correct classifications were: $97.5 \%$ for C. semerme, $100 \%$ for C. strumosum and $81.8 \%$ for C. magdaleni (Table I, Fig. 2).

The proportion of C. semerme, C. strumosum and C. magdaleni individuals in the fourhorn sculpins in 1996-1997 were $98.3 \%, 0.3 \%$ and $1.4 \%$, respectively (total no of worms being 2,516) (Table II). The prevalences of C. semerme, C. magdaleni and C. strumosum infections were $81.9 \%, 8.9 \%$ and $3.1 \%$ in the central area and
$9.9 \%, 2.5 \%$ and $0 \%$ in the coastal area, respectively. Majority $(70 \%)$ of the sculpins in the central area were infected with only $C$. semerme (Table III). The most common double infection was the C. semerme-C. magdaleni assemblage. Except one fish, fourhorn sculpins infected with either $C$. strumosum or $C$. magdaleni were also infected with $C$. semerme (Table III). The occurrence of C. semerme (Pearson $\chi_{1}^{2}=94.926, p<0.001$ ) and C. semerme-C. magdaleni assemblages (Pearson $\chi_{1}^{2}=$ 5.156, $p=0.023$ ) were both significantly greater in the central area than in the coastal waters. C. strumosum occurred only in the central area (Table III).

When studying the relationship between the habitats and the time periods, the logistic regression model for C. semerme in the Bothnian Bay included the terms "habitat" (change in log likelihood if term removed $=$ $10.317, \mathrm{df}=1, p=0.001$ ), "time period" (change in log likelihood if term removed $=7.680, \mathrm{df}=1, p=0.006$ ) and "interaction of habitat and time period" (change in $\log$ likelihood if term removed $=4.883, \mathrm{df}=1, p=0,027$ ) The prevalence of the $C$. semerme infection in the central area was nearly the same in the two time periods but in the coastal area the level of the infection had decreased significantly from $23 \%$ to $9.9 \%$ (Table IV In the case of "C. strumosum" the main effects ("habitat" and 


\begin{tabular}{|c|c|c|c|c|c|}
\hline \multicolumn{2}{|c|}{ Trunk length (mm) } & \multicolumn{2}{|c|}{ Cystacant stage } & \multicolumn{2}{|c|}{ Adult stage } \\
\hline & $\mathrm{n}$ & $\mathrm{x}$ & range & $\mathrm{x}$ & range \\
\hline C. semerme & 60 & 1.9 & $1.5-2.3$ & $4.0^{* *}$ & $3.0-5.0^{* * *}$ \\
\hline C. strumosum & 7 & 3.1 & $2.5-3.5$ & $6.5^{*}$ & $5.0-7.0^{*}$ \\
\hline C. magdaleni & 33 & 2.7 & $1.7-3.6$ & $4.7^{*}$ & $3.6-5.3^{*}$ \\
\hline \multicolumn{2}{|c|}{ Proboscis length $(\mu \mathrm{m})$} & \multicolumn{2}{|c|}{ Cystacanth stage } & \multicolumn{2}{|c|}{ Adult stage } \\
\hline & $\mathrm{n}$ & $\mathrm{x}$ & range & $\mathrm{x}$ & range \\
\hline C. semerme & 60 & 510 & $340-580$ & $\square$ & $500-600^{* *}$ \\
\hline C. strumosum & 7 & 590 & $510-680$ & $653^{*}$ & $624-700^{*}$ \\
\hline C. magdaleni & 33 & 420 & $300-500$ & $476^{*}$ & $440-500^{*}$ \\
\hline
\end{tabular}

Table I. - The length of the trunk and proboscis ( $\mathrm{mm}$ ) of the cystacanths of three Corynosoma species in the Bothnian Bay in 1996-1997. * from Nickol et al., 2002, ** from Petrochenko, 1958, $\square=$ unavailable.

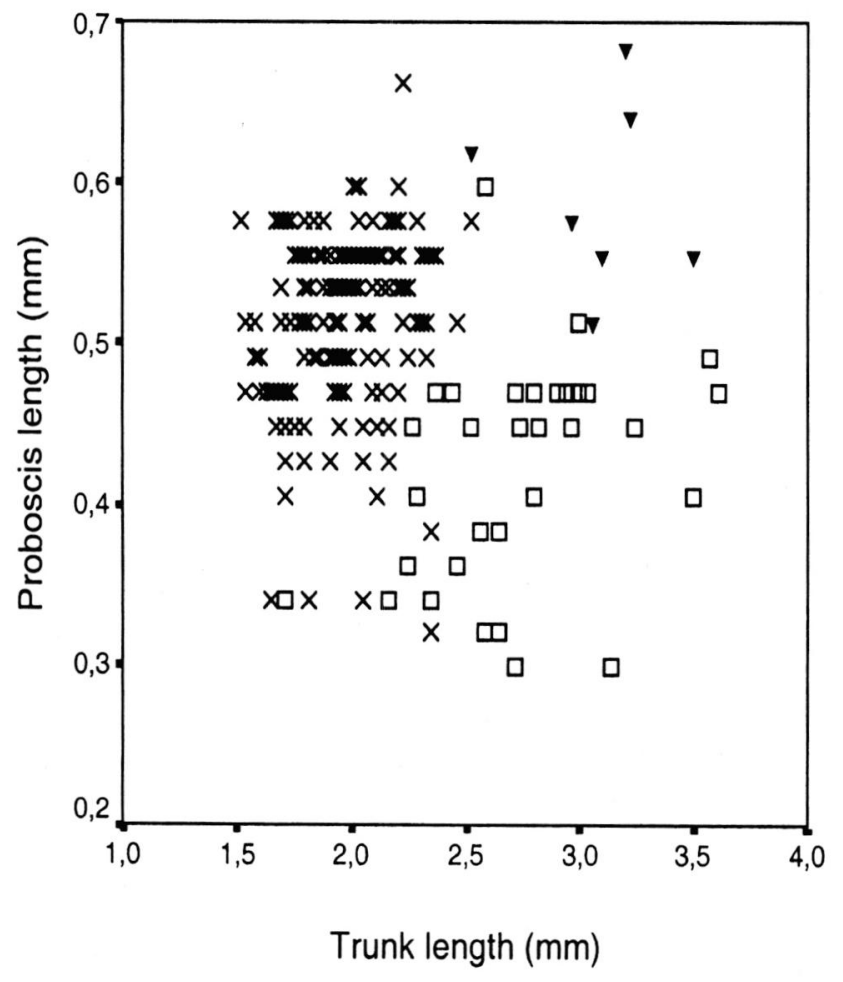

Fig. 2. - The length of the proboscis and trunk (mm) of the three Corynosoma species in fourhorn sculpins (M. quadricornis) in the Bothnian Bay in 1996-1997. Each symbol represents a single parasite specimen, $\mathrm{x}=C$. semerme, $\boldsymbol{\nabla}=$ C. strumosum and $\square=C$. magdaleni .

\begin{tabular}{lcccc}
\hline Parasite & No of worms & $\mathbf{\%}$ & Range & $\begin{array}{c}\text { Mean } \\
\text { abundance }\end{array}$ \\
\hline C. semerme & 2,472 & 98.3 & $1-60$ & 7.27 \\
C. strumosum & 8 & 0.3 & 1 & 0.02 \\
C. magdaleni & 36 & 1.4 & $1-3$ & 0.11 \\
\hline
\end{tabular}

Table II. - The proportion of Corynosoma species in fourhorn sculpins in the Bothnian Bay in 1996-1997 (number of fish $=340$ ).

"time period") were significant. The logistic regression model included the term "habitat" (change in log likelihood if term removed $=29.132$, df $=1, p<0.001$ ) and the term "time period" (change in log likelihood if term removed $=10.142, \mathrm{df}=1, p=0.001)$. The prevalence of "C. strumosum" decreased in both areas (Table IV).

The bull-routs $(n=42)$ from the southern part of the Gulf of Bothnia harboured only two species: C. semerme (prevalence $54.7 \%$, mean intensity 4.5 ) and C. strumosum (prevalence $9.5 \%$, mean intensity 1.5 ).

\section{DISCUSSION}

Whe three Corynosoma species that occurred in grey seals from the Archipelago Sea in the southern part of the Gulf of Bothnia (Nickol et al.,

\begin{tabular}{|c|c|c|c|c|c|}
\hline & \multicolumn{2}{|c|}{$\begin{array}{c}\text { Coastal } \\
(n=81)\end{array}$} & \multicolumn{2}{|c|}{$\begin{array}{c}\text { Central } \\
(n=259)\end{array}$} & \multirow[b]{2}{*}{$p$} \\
\hline & $\%$ & $\mathrm{n}$ & $\%$ & $\mathrm{n}$ & \\
\hline C. semerme & 8.6 & 7 & 70.3 & 182 & $<0.001$ \\
\hline C. magdaleni & 1.2 & 1 & 0 & 0 & NS \\
\hline C. semerme + C. magdaleni & 1.2 & 1 & 8.5 & 22 & 0.023 \\
\hline C. semerme + C. strumosum & 0 & 0 & 2.7 & 7 & NS \\
\hline C. semerme + C. magdaleni + C. strumosum & 0 & 0 & 0.4 & 1 & NS \\
\hline
\end{tabular}

Table III. - The occurrence of Corynosoma species and their assemblages in fourhorn sculpins (M. quadricornis) from the coastal and the central areas of the Bothnian Bay in 1996-1997. The frequences of the Corynosoma assemblages were tested by Pearson $\chi^{2}$-test and its significance level $(p)$ are given. 


\begin{tabular}{lcccc}
\hline C. semerme & $\begin{array}{c}\text { 1977-1982 } \\
\text { Central }\end{array}$ & $\begin{array}{c}\text { 1996-1997 } \\
\text { Central }\end{array}$ & $\begin{array}{c}\text { 1977-1982 } \\
\text { Coastal }\end{array}$ & $\begin{array}{c}\text { 1996-1997 } \\
\text { Coastal }\end{array}$ \\
\hline No fish & 515 & 259 & 296 & 81 \\
Prevalence (\%) & 82.9 & 81.9 & 23.0 & 9.9 \\
Mean Abundance & 10.1 & 9.4 & 1.2 & 0.3 \\
Number of parasites & 5,227 & 2,445 & 359 & 27 \\
Max / fish & 77 & 60 & 44 & 16 \\
& $\mathbf{1 9 7 7 - 1 9 8 2}$ & $\mathbf{1 9 9 6 - 1 9 9 7}$ & $\mathbf{1 9 7 7 - 1 9 8 2}$ & $\mathbf{1 9 9 6 - 1 9 9 7}$ \\
& Central & Central & Coastal & Coastal \\
“C. strumosum" & & 259 & 296 & 81 \\
\hline Number of the fish & 515 & 13.5 & 9.1 & 2.5 \\
Prevalence (\%) & 21.0 & 0.2 & 0.1 & 0 \\
Mean Abundance & 0.3 & 49 & 37 & 2 \\
Number of parasites & 159 & 3 & 3 & 1 \\
Max/ fish & 6 & & & \\
\hline
\end{tabular}

Table IV. - Comparison of C. semerme and "C. strumosum"infections between the periods of 1996-1997 and 1977-1982 in fourhorn sculpins from the Bothnian Bay. "C. strumosum" included both C. magdaleni and C. strumosum

2002) and in ringed seals from the Bothnian Bay in the northern part of the Gulf of Bothnia (Valtonen \& Helle, unpubl.) were also all found in the paratenic fish host, the fourhorn sculpin in the Bothnian Bay. Corynosoma semerme was the dominant Corynosoma species in ringed seals throughout the 1970s to 1990s (Helle \& Valtonen, 1980, 1981; Valtonen, 1983b; Valtonen \& Helle, 1988; Valtonen, unpubl.). The proportion of $C$. emerme from all acanthocephalan cystacanths in the fourhorn sculpin was similar in 1996-1997 to that in $1977-1982(98.3 \%$ and $97.0 \%$, respectively (see Valtonen, 1983a). The respective figures for " $C$. strumosum" were $1.7 \%$ in 1996-1997 compared to $3.0 \%$ in 1977-1982.

The trunk length of $C$. semerme cystacanths differed distinctly from the other two Corynosoma species, whereas the cystacanths of $C$. magdaleni and C. strumosum were not easily separated. Many anatomical features of C. strumosum were similar to but larger than those of C. magdaleni. However, the most conspicuous differences between $C$. strumosum and C. magdaleni at the cystacanth stage, the shorter proboscis, the more slender trunk and the greater extent of ventral trunk spines in C. magdalen $i$ were sufficient to differentiate the two species in the paratenic host (see also Nickol et al., 2002). The occurrence of the parasites in the paratenic host is dependent on intermediate and definitive host abundance (Brattey et al., 1990; Lunneryd, 1991). In the Bothnian Bay, ringed seals (Phoca bispida baltica) are encountered abundantly in the central area but they visit coastal waters during a few weeks in OctoberNovember (Helle \& Valtonen, 1981). The other definitive host, the grey seal (Halichoerus grypus) (Nickol et al., 2002), visits the Bothnian Bay regularly in the spring. However during the latter part of the 1990s, summer colonies of grey seals increased in the study area and especially in the area of our coastal site (Helle, pers. comm.). The population of the intermediate host, the amphipod Monoporeia affinis, has been more stable in the deeper central area than in the shallower coastal area throughout the studies (Andersin et al., 1978; Lindström, 1991; Wikner, 1996). The lower prevalence and abundance of Corynosoma infections in the coastal area compared to the central area arises from the greater variability and more patchy occurrence of both the definitive seal hosts and the intermediate amphipod host in the coastal area.

The prevalence and mean abundance of $C$. semerme in the deeper study site was nearly the same in the two periods (separated by 14 years, whole time scale of these studies extending over 21 years). It shows that C. semerme, the most common marine acanthocephalan species in seals (Dailey, 1975), has adapted to the brackish water ecosystem and survived through the varying history of the Baltic Sea following the latest glacial period (Winterhalter et al., 1981). Corynosoma strumosum is also a widespread species in oceanic seals (Shults, 1982; Measures \& Gosselin, 1994). However, this study shows that C. magdalen $i$ is more prevalent than C. strumosum in the Bothnian Bay.

In the definitive host, Corynosoma worms mature in two to three weeks (see Valtonen \& Helle, 1982). The life cycle of the intermediate host, M. affinis, is two years in the Bothnian Bay (Andersin et al, 1984), whereas the paratenic host, fourhorn sculpin, lives up to eight years (Timole \& Luotonen, 1986). We suggest that the stability of the Corynosoma population in the area is maintained mainly in their paratenic fish hosts. We conclude that paratenic hosts are a reservoir of Corynosoma individuals stabilizing the variation in Corynosoma populations, which explains the similarity in C. semerme infections throughout the 21 years covered by this study. However, the prevalence of " $C$. strumosum" in the fourhorn sculpins decreased between the two periods. The reason for this is most probably the disappearance of the preferred paratenic fish host of "C. strumosum", the bull-rout, from the $1990 \mathrm{~s}$ onwards (Timola, pers. comm.).

The disappearance of $M$. scorpius is a result from the overall decline in salinity throughout the Baltic Sea during the last 25 years; major saline water inflow pulses have not been repeated since 1976 (Wikner, 1996). The bull-rout is a marine species (Valtonen \& Crompton, 1990), whereas the fourhorn sculpin is a stenothermal species that favours brackish water rather than a marine environment (Timola et al., 1984) and it is even found in several lakes in Finland as glacial relict (Savolainen, 1975). It is also supported by our findings of C. strumosum in M. scorpius in the more southern and marine Gulf of Bothnia, even though C. magdaleni is also common in the area (Nickol et al., 2002). 
Host specificity of Corynosoma species at the paratenic host level is low (Nickol, 1985). So far we cannot define the role of the fourhorn sculpin in transferring C. magdaleni and C. strumosum to seals. However, Corynosoma infections were much lower in all other paratenic fish species than in fourhorn sculpin during the study of Valtonen (1983a). In 1996-1997 we found only four C. magdaleni cystacanths from four ruffe (Gymnocephalus cernuus) (151 examined) and three C. strumosum from Baltic herring (Clupea harengus membras) $(\mathrm{n}=904)$ (Sinisalo et al., unpubl.). Other fish species were not studied in 1996-1997.

The stability of C. semerme over the 21 years period compared to the decrease of "C. strumosum" at the same time is interesting. Why did the disappearance of the bull-rout not also affect the C. semerme population? During the previous period $82.9 \%$ of all C. semerme specimens were found in M. quadricornis and only $11.8 \%$ of them in M. scorpius. In the case of "C. strumosum", $39.0 \%$ of the specimens were found in M. quadricornis and $30.1 \%$ in M. scorpius (Valtonen 1983a). Thus the disappearance of the bullrout is having a more powerful effect on the population of "C. strumosum" than on that of C. semerme. The complex life cycles of the parasites depend largely on the trophic interactions between several different hosts (Minchella \& Scott, 1991). Therefore, the constant presence of parasites in a host will provide extensive information on the stability in an ecosystem (Marcogliese \& Cone, 1997). Even though we studied the Corynosoma infections only during two periods, both periods were covered by extensive data sets collected from exactly the same areas and the same seasonal timing. In a multixenous parasite species, where different stages of parasites occur in three trophic levels of the ecosystem, the temporal variation in the compound communities is stabilized much better than in monoxenous parasites. In the case of Corynosoma, the long living cystacanth stages in paratenic hosts act as a stabilizing reservoir of parasites that can infect the definitive hosts.

\section{ACKNOWLEDGEMENTS}

W re wish to thank Mr. Osmo Timola Phil.lic. and the staff of Bothnian Bay Research Station for supplying us with sculpins and Dr. J. Taskinen for the statistical advices. We are grateful to Professor Brent Nickol for checking the identification of C. magdaleni cystacanths and Dr. R. Siddall and Prof. R. Jones for checking the English of the manuscript. The summary was kindly translated into French by Dr. Pierre Sasal.

\section{REFERENCES}

Andersin A.B., Lassig J., Parkkonen L. \& Sandler H. Long term fluctuations of the soft bottom macrofauna in the deep areas of the Gulf of Bothnia 1954-1974; with special reference to Pontoporeia affinis Lindström (Amphipoda). Finnish Marine Research, 1978, 244, 137-144.

Andersin A.B., Lassig J., Parkkonen L. \& Sandler H. On the biology and production of Pontoporeia affinis Lindstr. in the Gulf of Bothnia. Limnologica, 1984, 15, 395-401.

Andreasson S. \& Petersson B. The fish fauna of the Gulf of Bothnia. Finnish Marine Research, 1982, 244, 137-144.

Brattey J., Bishop C. \& Myers R. Geographic distribution and abundance of Pseudoterranova decipiens (Nematoda: Ascaridoidea) in the musculature of Atlantic cod, Gadus morbua, from Newfoundland and Labrator. Canadian Bulletin of Fisheries and Aquatic Sciences, 1990, 222, 67-82.

Bush A.O., Lafferty K.D., Lotz J.M. \& Shostak A.W. Parasitology meets ecology on its own terms: Margolis et al. revisited. The Journal of Parasitology, 1997, 83, 575-583.

DAILEY M.D. The distribution and intraspecific variation of helminth parasites in Pinnipeds. Rapport et Procès-verbaux des Réunions de la Commission internationale pour L'Exploration Scientifique de la Mer Méditerranée, 1975, 169, 338-352.

Delyamure S.L., Popov V.N. \& Trashchenkov A.N. A study of the helminth fauna of seals in the Baltic Sea and Lake Ladoga. Doklady Vysshei Shkoly, Biologicheskie Nauki, 1980, 7, 43-45.

FRIMETH J.P. A survey of the parasites of nonanadromous and anadromous brook charr (Salvelinus fontinalis) in the Tabusintac River, New Brunswick, Canada. Canadian Journal of Zoology, 1987a, 65, 1354-1362.

FRIMETH J.P. Potential use of certain parasites of brook charr (Salvelinus fontinalis) as biological indicators in the Tabusintac River, New Brinswick, Canada.Canadian Journal of Zoology, 1987b, 65, 1989-1995.

HaApala J. \& Alenius P. Temperature and salinity statistics for the Northern Baltic Sea 1961-1990. Finnish Marine Research, 1994, 262, 51-121.

HaRding K.C. \& HärKönEn T. Development in the Baltic grey seal (Halichoerus grypus) and ringed seal (Phoca hispida) populations during the $20^{\text {th }}$ Century. Ambio, 1999, 28, 619627.

Helle E. Reproduction, size and structure of the Baltic ringed seal population of the Bothnian Bay. Acta Universitatis Ouluensis series A, 1980, No. 106, Biologica No. 11.

Helle E. The decrease in the ringed seal population of the Gulf of Bothnia in 1970-84. Finnish Game Research, 1986, 44, 28-32.

Helle E. \& Valtonen E.T. On the occurrence of Corynosoma spp. (Acanthocephala) in ringed seals (Pusa bispida) in the Bothnian Bay, Finland. Canadian. Journal of Zoology, 1980, 58, 298-303.

Helle E. \& Valtonen E.T. Comparison between spring and autumn infection by Corynosoma (Acanthocephala) in the ringed seal Pusa bispida in the Bothnian Bay of the Baltic Sea. Parasitology, 1981, 85, 287-296. 
HÄRKÖNEN T. \& LUNNERYD S.G. Estimating Abundance of ringed seals in the Bothnian Bay. Ambio, 1992, 21, $497-$ 503.

LINDSTRÖM M. Factors affecting the horizontal migration of the amphipod Pontoporeia affinis Lindström. I. Recording method and response to water currents. Journal of Experimental Marine Biology and Ecology, 1991, 150, 149-162.

LunNeryd S. Anisakid nematodes in the harbour seal, Phoca vitulina, from Kattegat-Skagerrak and the Baltic. Ophelia, 1991, 34, 105-115.

Marcogliese D.J. \& Cone D.K. Food webs: a plea for parasites. Trends in Ecology and Evolution, 1997, 12, 320-325.

Measures L. \& Gosselin J.-F. Helminth parasites of ringed seal, Phoca hispida, from Northern Quebec, Canada. Journal of the Helminthological Society of Washington, 1994, 61, 240-244

Minchella D. \& Scott M.E. Parasitism: a cryptic determinant of animal community structure. Trends in Ecology and Evolution, 1991, 6, 250-254.

Montreuil P. Corynosoma magdaleni sp. nov. (Acanthocephala), a parasite of the grey seal in eastern Canada. Canadian Journal of Zoology, 1958, 36, 205-215.

NiCKOL B.B. Epizootiology. In: Biology of the Acanthocephala. Crompton D.W.T. \& Nickol B.B. (eds.), Cambridge University Press, Cambridge, 1985, 307-346.

Nickol B.B., Valtonen E.T. \& Helle E. Corynosoma magdaleni in grey seals from SW Finland, Baltic Sea, with ememded description of C. magdaleni and C. strumosum. Journal of Parasitology, 2002, 88, 1222-1229.

Petrochenko V.J. Acanthocephala of domestic and wild animals. Skrjabin, K.J. (ed.). All-Union society of helminthologists, Vol. II, 1958, translated from Russian, Israel Program for Scientific Translation, Jerusalem, 113-115.

Popov V.N., Jurakhno M.V. \& Skriabin V.A. Helminth fauna of the Okhotsk ringed seal from the Patience Bay and Laperouse Strait. Parasitologiva, 1980, 14, 48-55.

Savolainen E. Distribution and food of Myoxocephalus quadricornis (L.) (Teleostei, Cottidae) in fresh waters of eastern Finland. Annales Zoologici Fennici, 1975, 12, 271-274.

SHults L. Helminths of the spotted seal Phoca largha from the Gering Sea. Journal of Wildlife Diseases, 1982, 18, 5962.

Strauss V., Claussen D., Jäger M., Ising S., Schneider T. \& STOYE M. The helminth fauna of the common seal (Phoca vitulina vitulina, Linné 1758) from the Wadden Sea in Lower Saxony. Journal of Veterinary Medicine B, 1991, 38, 641-648

Timola O. \& Luotonen H. Age distribution and growth of the fourhorn sculpin, Myoxocephalus quadricornis, in the NE Bothnian Bay and the Archipelago Sea. Bothnian Bay Reports, 1986, 4, 25-32.

Timola O., Hyvärinen R. \& Laine A. Distribution of the fourhorn sculpin, Myoxocephalus quadricornis, in the NE Bothnian Bay and the Archipelago Sea. Bothnian Bay Reports, 1986, 4, 25-32.

VALTONEN E.T. Relationships between Corynosoma semerme and $C$. strumosum (Acanthocephala) and their paratenic fish hosts in the Bothnian Bay, Baltic sea. Acta Universitatis Ouluensis series A, 1983a, No. 155. Biologica No. 21, $1-32$.

VALTONEN E.T. On the ecology of Echinorbynchus salmonis and two Corynosoma species (Acanthocephala) in the fish and seals of the Northern Gulf of Bothnia. Acta Universitatis Ouluensis series A ,1983b, No. 156., Biologica No. 22, $1-48$.

Valtonen E.T. \& Crompton D.W.T. Acanthocephala in fish from the Bothnian Bay, Finland. Journal of Zoology. Proceedings of the Zoological Society of London, 1990, 220, 619-639.

Valtonen E.T. \& Helle E. Experimental infection of laboratory rats with Corynosoma semerme (Acanthocephala). Parasitology, 1982, 85, 9-19.

Valtonen E.T. \& Helle E. Host-parasite relationships between two seal populations and two species of Corynosoma (Acanthocephala) in Finland. Journal of Zoology, 1988, 214, 361-371

WIKNER J. (convener). Gulf of Bothnia (Bothnian Bay, Bothnian Sea, Åland Sea, Archipelago Sea) Third periodic assessment of the state of the marine environment of the Baltic Sea, 1989-93; Background document. Baltic Sea Environment Proceedings, 1996, No. 64 B, 28-46.

Winterhalter B., Floden T., Ignatius H., Axberg S. \& NieMISTÖ L. Geology of the Baltic Sea. In: The Baltic Sea, Voipio A. (ed.), Elsevier Scientific Publishing Company, Amsterdam, 1981, 1-121.

Reçu le 23 janvier 2003 Accepté le 23 mai 2003 